\title{
RETROSPECTIVE DATA ANALYSIS OF ANTERIOR CERVICAL DISCECTOMIES AND FUSION WITHOUT PLATE AND SCREWS
}

\author{
Artis Gulbis ${ }^{1,2}$, Edgars Ginevičs ${ }^{2}$, Agnese Ozoliṇa 1,3,\# , Kaspars Ruks ${ }^{1}$, \\ Indulis Vanags ${ }^{3,4}$, and Konstantīns Kalnbērzs ${ }^{2}$ \\ ${ }^{1}$ ORTO Clinic, 1a Bukultu Str., LV-1005, Rīga, LATVIA \\ 2 Faculty of Medicine, University of Latvia, 19 Raiṇa Blvd., LV-1586, Rīga, LATVIA \\ ${ }^{3}$ Department of Anaesthesiology and Reanimatology, Rīga Stradiṇš University, 16 Dzirciema Str., LV-1007, Rīga, LATVIA \\ ${ }^{4}$ Department of Anaesthesiology and Reanimatology, Pauls Stradinš Clinical University Hospital, \\ 13 Pilsoṇu Str., LV-1002, Rīga, LATVIA \\ \# Corresponding author, agnese.ozolina@icloud.com \\ Communicated by Dainis Krieviṇš
}

\begin{abstract}
Surgical intervention in cervical disease can relieve neurological symptoms and improve life quality. This study aimed to analyse retrospective data of microscope-assisted anterior cervical discectomy and fusion (ACDF) surgeries. The retrospective study was carried out at the ORTO clinic, Riga, Latvia, from 2013 to 2017. Data from 198 patients were extracted retrospectively. Data on patient gender, age, diagnosis, extent of operation, type of cage and the overall height of the implants were used. Comparative analysis was carried out with the SPSS 22 software. $\mathrm{P}<$ 0.05 represented statistical significance. During the study period, 198 elective ACDF were carried out with increasing number of surgeries: 25 cases in 2013, 43 in 2014, 38 in 2015, 44 in 2016, and 48 in 2017. ACDF were significantly more often performed for females ( $n=117,59 \%)$ compared to males $(n=81,41 \%$; $p<0.003)$. Women were older with an average age of $50 \pm 1$ years than men (age $46 \pm 1 ; p=0.007$ ). The mean surgery time was $1.5 \pm 1$ hours and the mean hospitalisation time was $3 \pm 1$ days. Four types of cages were used in similar number of operation: Cervios Peek Chronos C (24\%), Syncage C (21\%), EIT 3D print (29\%), Cervios C Peek (26\%); $\mathrm{p}=0.2$, regardless of patient age or gender. Most often, in 98 cases, the overall height of implants was 6-10 $\mathrm{mm}$. The maximal height was $22 \mathrm{~mm}$, where two patients underwent three-level, and one had a four-level discectomy. The most prevalent disc lesion levels were C5/6 and C6/7, followed by $\mathrm{C} 4 / 5$ and $\mathrm{C} 3 / 4$. One- and two-level discectomies were performed in similar numbers: 95 and 81 cases. However, only 20 patients underwent three level and two patients had four level discectomies in 2016 and 2017. Two level discectomy at C5/6, C6/7 was carried out significantly more often for women (55 vs. 26; $\mathrm{p}=0.01$ ), and for men 1-level lesion was more common in C6/7; $\mathrm{p}=0.04$. The overall incidence of cage subsidence was $5.5 \%$, and the highest incidence was $24 \%$ when a Syncage $C$ was used. The ACDF appears to be performed increasingly more often, particularly, in females. The most frequent operation was in one or two cervical levels; including level C6/7 in both genders. In the last years, three- and four-level cervical discectomies have become one of the surgical opportunities. Choice of cage was not influenced by patient gender and age, while cage biophysical and biochemical properties may influence the choice.
\end{abstract}

Key words: anterior cervical discectomy, cervical cages.

\section{INTRODUCTION}

Ageing as an inevitable biological process causes changes in the cervical spine. Consequently, changes in vertebral joints, intervertebral discs, ligaments lead to structural and functional disabilities (Rao, 2003).
Anterior cervical discectomy and fusion (ACDF) surgery is the most commonly used decompressive procedure in the cervical spine. This approach requires minimal intervention of the spinal cord or cervical roots and allows for removal of both lateral and midline disc herniation and osteophytes (Rao, 2003; Shamji et al., 2013; Neill, 2016). Nevertheless, 
disadvantages include injury to the carotid artery, trachea, esophagus, or recurrent laryngeal nerve. Moreover, the risk of development of pseudo arthrosis and further degenerative changes of adjacent segments from the level where cervical disc implant is inserted still exist (Fountasi et al., 2007).

For ACDF surgery, the main indications are cervical disc herniation, spondylotic myelopathy, symptomatic cervical spondylosis and multiple level discogenic disease (Hermansen, 2015; Woods and Hilibrand, 2015; Iyer and Kim, 2016). At the same time, a few contraindications exist, such as active systemic or located infection, severe osteoporosis or osteopenia, which are conditions that reduce the likelihood of fusion and result in cancellation of surgical treatment (Montgomery and Brower, 1992; Nikolaidis et al., 2010).

Cervical spondylosis and radiculopathy refers to a progressive degenerative process affecting the cervical vertebral bodies and intervertebral discs. The most commonly affected segment in individuals with symptomatic radiculopathy is C 6/7, followed by C 5/6, C $4 / 5$ and C7/Th1 (Radhakrishnan et al., 1994). A prolonged process can lead to stenosis of the central spinal canal, compressing the cervical spinal cord and producing a syndrome of spinal cord dysfunction known as cervical spondylotic myelopathy (Bakhsheshian et al., 2017). Myelopathy occurs in 5 to 10 percent of patients with symptomatic cervical spondylosis. The main symptoms of cervical spondylosis include neck pain and cervical radiculopathy (Fouya et al., 2010). Moreover, cervical spondylotic myelopathy is the most common cause of myelopathy in adults over 55 years, causing progressive disability and impairing the quality of life. This debilitating condition sometimes need to be solved by surgical intervention (Fouyas et al., 2010; Nikolaidis et al., 2010; Sham et al., 2013).

Nowadays, mainly ACDF surgery under microscope assistance is performed (Portnoy, 2001; Shamji et al., 2013; Neill, 2016). For successful outcome, a significant role is played by choice of the cage, due to their different biophysical and biochemical properties with designs constantly improving to maximise biocompatibility and osseointegration (Kurtz and Devine, 2007; Chong et al., 2015).

The aim of the study was to collect and analyse data from microscope-assisted anterior cervical discectomy and fusion surgeries without plate and screws during a four-year period of time.

\section{MATERIALS AND METHODS}

The study was approved by the Ethics Committee of University of Latvia. This study included 198 consecutive patients with cervical spondylosis surgically treated in the Orto Clinic, Rīga, Latvia, between January 2013 and December 2017. The study included the following data extracted retrospectively from medical records: patients gender, age, diagnosis, discectomy levels, type of cage and the overall height of implants. Four types of cages were used: Syncage C, Cervios Peek Chrono C, Cervios C Peek, and EIT 3D print. Inclusion was based on the following criteria: patients with herniated intervertebral discs diagnosed by clinical and radiographic methods, and compression of cervical spinal cord or nerve roots. For all patients, elective microscope-assisted ACDF without inserting plate and screws was performed. Comparative analysis was carried out according to the patient gender, age, diagnosis, extent of surgery, the overall height of implant and type of cage (Syncage C, Cervios Peek Chrono C, Cervios C Peek, EIT 3D print). The overall alignment of cervical implants was calculated as a sum of implanted cages in millimeters.

In our retrospective study four types of cages were used:

Syncage C - a system of curved or wedge-shaped implants and instruments. The system helps to distract the disc space and restore normal disc height and lordosis, thereby also widening the foramina. It provides an optimal implant/endplate interface, thus considerably limiting the risk of subsidence into the adjacent vertebrae. It stabilises the pathologically unstable segment and supports bone growth through the implant.

Cervios Chronos C Peek - Radiolucent PEEK Optima pre-filled with chronOS - a bone graft substitute consisting of pure b-tricalcium phosphate. Chronos compressive strength is similar to that of cancellous bone. Sharp teeth on the surface of the implant ensure primary stability and prevent migration of the cage. A roughened surface and chronos promote integration and bone on growth - even onto the teeth of the cage — for good secondary stability.

EIT 3D print - an implant made from titanium allowing for anterior stabilisation of the cervical spinal column. EIT Cellular Titanium provides an active fusion area, and the implant has $\sim 80 \%$ porosity, $\sim 650 \mu \mathrm{m}$ diamond pore size, and an open interconnected framework for optimal cell migration and proliferation. The implant is dome shaped to the endplate anatomy. A lateral wedge design provides for maximal contact of the uncovertebral joint. A suitable elasticity modulus avoids stress shielding and bone resorption.

Cervios C Peek - Radiolucent PEEK Optima without chronos substance. It allows bone fusion to occur through the Implant Cage. Pyramidal serration provides for better anchorage in the adjacent vertebral endplates. It provides resistance to implant migration and reduces the risk of implant expulsion.

Statistical analysis was performed using SPSS Statistics (Chicago, IL, Ver. 22). Descriptive and comparative statistics were used to compare groups according to gender, type of cage and age. Continuous variables were presented as mean \pm standard deviation (SD) and categorical variables as percentages $(\%)$. Comparisons between the groups were made using the Mann-Whitney $U$ test for non-parametric variables, and a two-sample t test or ANOVA for paramet- 
ric variables. The Chi- square test was used to analyse categorical data. Statistical significance was defined as $\mathrm{p}<0.05$.

The surgery was performed under general endotracheal anaesthesia. Patients were positioned in supine position with their neck in slight flexion, by placing the torus at the neck and fixing the head with medical adhesive tape. Both arms were placed at the patient's side to allow x-ray access with traction applied to the arms by an unscrubbed assistant at the foot of the table during the surgery. Transverse hemicollar incision was made parallel to the clavicle extending from the sternocleidomastoid muscle to the midline. The incision was taken through the subcutaneous fat to the surface of the platysma. The layer of deep cervical fascia was incised along the anterior border of the sternocleidomastoid muscle. Blunt dissection was used to develop the interval between the carotid sheath and the midline structures, staying close to the trachea. The fascia along the lateral edge of the superior belly of the omohyoid muscle was cut until the edge of the esophagus was visible. The anterior cervical spine was then exposed. Cautery was used in the midline over the cervical spine, followed by a "peanut sponge". A 22-gauge spinal needle was placed in the appropriate disc and a lateral x-ray was taken to verify anatomic level. The anterior annulus was incised and removed. The nucleus was removed and the cartilaginous endplate was peeled from the vertebral bodies above and below. Dissection should not be undertaken lateral to the upslope of Lushka's joint to assure protection of the vertebral arteries. After the disk has been removed, greater distraction can usually be achieved. This dissection was carried out laterally until the neural foramen could be entered with a nerve hook to verify that the nerve root was free and nuclear material had been removed. The Cage was tapped into the prepared disc space. A final X-ray was taken to verify position of the implant. Under absolute haemostasis, the vertebral body distractor was removed along with the screws. Bone wax was placed in the screw holes. The stability of cervical spine was checked. Tissue layers were closed and a soft cervical collar was applied.

\section{RESULTS}

In total, 198 consecutive patients ( 81 men and 117 women) $48 \pm 1$ years (mean \pm SD) of age scheduled for elective microscope-assisted ACDF were considered for inclusion during the time period from 2013 to 2017.

As demonstrated in Figure 1, ACDF was statistically significantly more often performed for females $(n=117,59 \%)$ compared to males $(\mathrm{n}=81,41 \%, p<0.003)$. On average, women were older compared to men, respectively, $50 \pm 1$ years vs. $46 \pm 1$ years; $p=0.007$. The youngest patient was a woman - a 24-year-old student with C 6/C7 disc foraminal protrusion, and the oldest was a 77-year-old pensioner with lesion of $\mathrm{C} 5 / 6$ and 6/7 disc levels due to para median disc protrusions. The mean surgery time was $1.5 \pm 0.5$ hours, and the average length of stay in hospital was $3 \pm 1$ days.

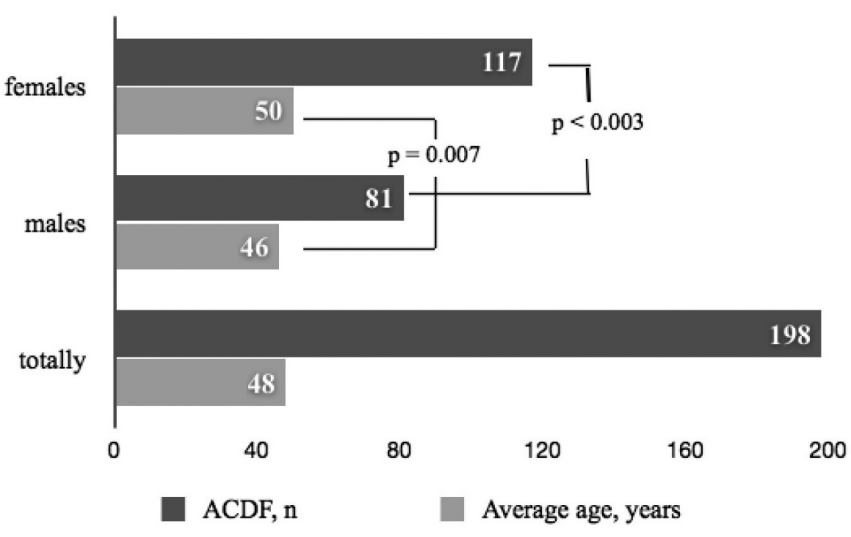

Fig. 1. Comparison of males and females regarding number of surgeries and age undergoing anterior cervical discectomy and fusion (ACDF) surgery.

In 2013, 25 ACDF without plate and screws were performed. The number of surgeries increased in 2014 to 43 patients and in 2015 to 38 cases. The number of surgeries continued to increase in 2016, to 44 operations, and in 2017 reached 48 operations per year (Fig. 2).

During the analysed time period, four types of cages were used with similar proportions: Cervios Peek Chrono C ( $\mathrm{n}=$ $47,24 \%)$, Syncage C $(n=41,21 \%)$, EIT 3D print $(n=58$, $29 \%)$ and Cervios C Peek $(\mathrm{n}=52,26 \%) ; p=0.2$, regardless of patient age or gender. Most often, in 98 (49\%) cases, the overall height of implants was $6-10 \mathrm{~mm}$, followed by $11-15 \mathrm{~mm}(\mathrm{n}=72,39 \%)$ and $16-20 \mathrm{~mm}(\mathrm{n}=17,8.5 \%)$. The maximal overall height of cervical implants was 21-25 $\mathrm{mm}$, and for these cases, two patients underwent 3-level (Cervicos C Peek implants), and one patient had 4-level (EIT 3D implants) discectomy.

The most prevalent lesion levels were $\mathrm{C} 6 / 7$ and $\mathrm{C} 5 / 6$, followed by $\mathrm{C} 4 / 5$ and $\mathrm{C} 3 / 4$. Ninety-five patients (48\%) had 1-level lesion and eighty one $(41 \%)$ had 2-level lesions. Surprisingly, the extent of surgery as defined by number of discectomy levels, appeared to increase in the last two years, as there were 20 cases $(9.8 \%)$ of 3 -level discectomies

\section{ACDF surgeries per year from 2013 till 2017}

50

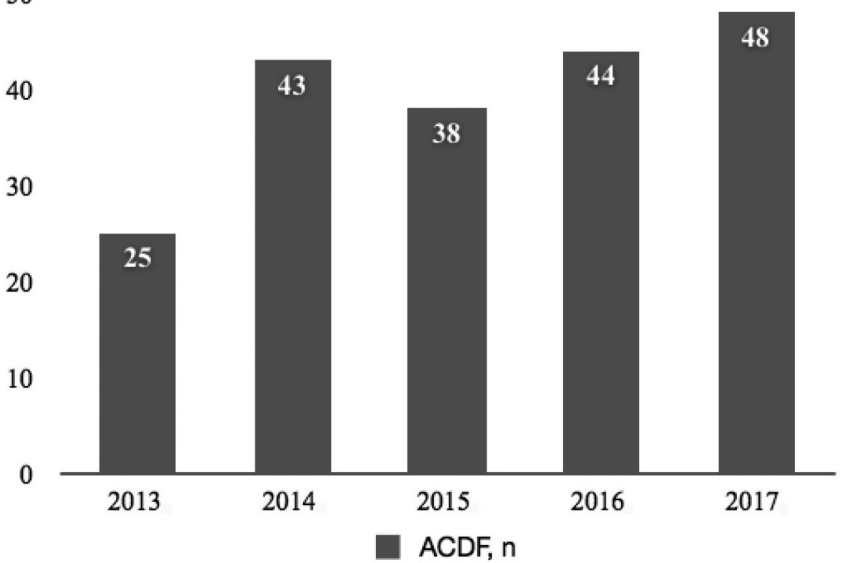

Fig. 2. Anterior cervical discectomy and fusion (ACDF) surgeries in the analysed time period from 2013 till 2017. 


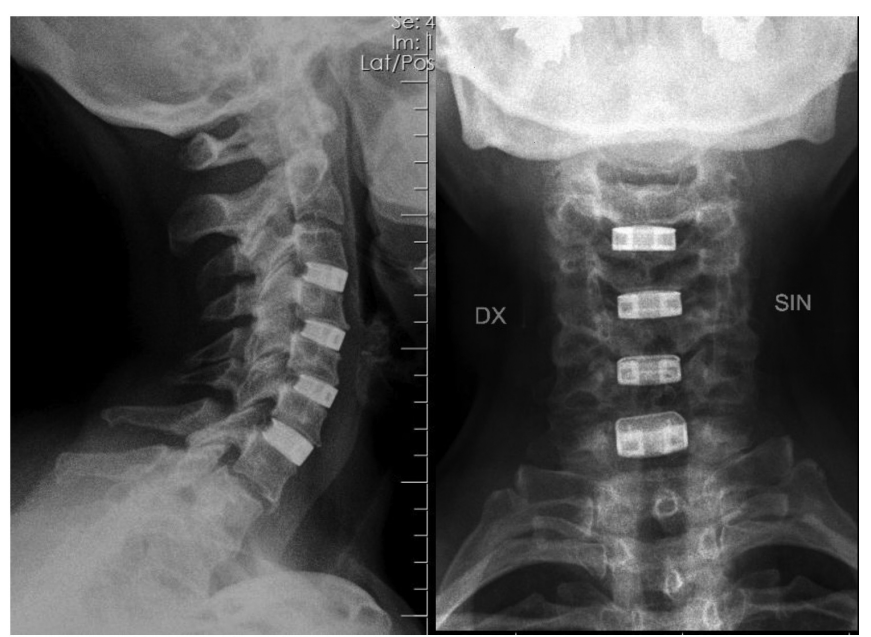

(a)

(b)

Fig. 3. X-ray image in lateral (a) and in anterior-posterior (b) position on the second postoperative day after four-level C 3/4, C 4/5, C 5/6, C 6/7 anterior cervical discectomy and fusion surgery in a 64 year-old woman with cervical spondylosis and cervical stenosis. The overall alignment of C3-C7 was 22 millimetres. The physiological lordosis was restored.

including C3-C6, and 4-level discectomy in two cases (1\%) presented from $\mathrm{C} 4-\mathrm{C} 7$. The case of 4-level cervical discectomy is shown in Figure 3. No complications of lordosis or kyphosis of cervical alignment were observed during the postoperative cervical $\mathrm{x}$-ray examination.

For women, statistically more often 2-level lesions in C 5/6 and 6/7 levels were detected and consequently two level ACDF surgery was performed, compared to men (respectively, 55 cases (47\%) vs. $26(32 \%) ; p=0.01)$. Although, 1 -level discectomy was performed in similar frequency between males and females in 47 vs. 48 cases, for men 1-level lesion occurred most frequently in $\mathrm{C} 6 / 7$ level; $p=0.04$, but for women in $\mathrm{C} 5 / 6$ level; $p=0.01$. Nevertheless, there were no significant differences between gender in 3-level and 4-level ACDF surgeries; females tended to more frequently undergo 3-level discectomy, compared to males. Comparative analysis between males and females depending on surgery levels is shown in Figure 4 a-c.

Subsidence of the cage occurred in ten of 41 patients with Syncage C cage (C 6 /7 level) and one subsidence occurred with a EIT 3 D printed cage. Additionally, pseudo arthrosis for nine patients with Cervios Chronos Peek C and Cervios $\mathrm{C}$ Peek cage was discovered. There were no serious complications, such as cerebrospinal fluid leakage, screw loosening, implant displacement, delayed healing, or death after the surgical procedure.

\section{DISCUSSION}

The retrospective study involved 198 patients, including 117 females and 81 males, in the time period from 2013 to 2017, who underwent ACDF elective surgery without plate and screws. The study revealed that the number of ACDF operations are increasing, particularly in women, and most often one or two cervical levels were restored, including

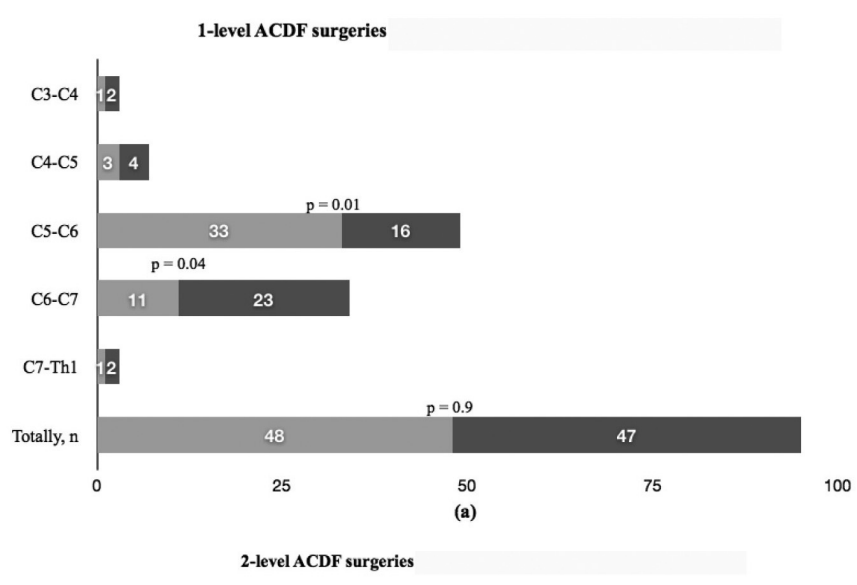

$\mathrm{C3}-\mathrm{C4}, \mathrm{C4}-\mathrm{CS} \quad 12$

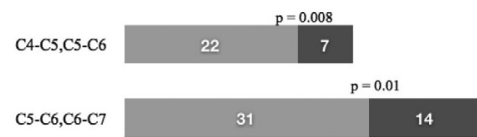

C6-C7,C7-Thl
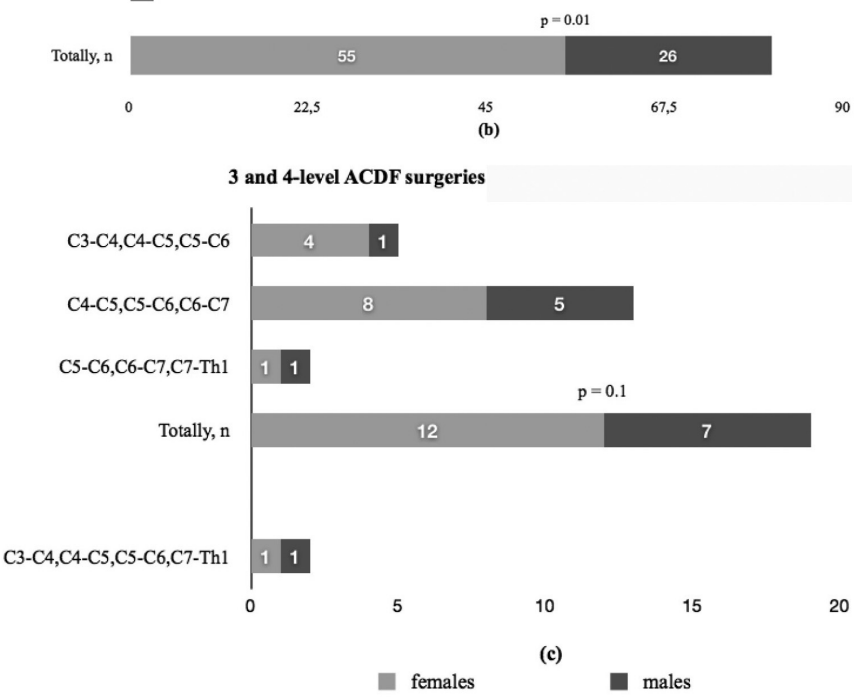

Fig. 4. Number of one-level (a), two-level (b), three- and four-level (c) anterior cervical discectomy and fusion (ACDF) surgeries in males and females.

level C 6/7, in both of genders. Moreover, in the last years three and four level ACDF surgeries were successfully performed.

The anterior approach to the cervical spine constitutes is a well-established surgical strategy, and one of the most commonly performed spinal procedures (Shamji et al., 2013; Woods and Hilibrand, 2015; Tasiou et al., 2017). Radiculopathy and myelopathy is cured by making discectomies at the cervical part of the spine, but also the sagittal balance is improved and thus other spine curves also become closer to the physical norm (Rao, 2003; Kim et al., 2015).

During the last five years, human lifestyle has changed. According to the World Health Organization (WHO) data, approximately $10 \%$ of adults have suffered from pain at the cervical part. For some of those patients pain becomes 
chronic leading to decreased working skills and even invalidity, by severely decreasing the quality of life (Rao, 2003; Woods and Hilibrand, 2015; Kim et al., 2016). Our results are consistent with several recent investigators showing that the incidence of diseases tends to increase and one of the most affected area of the spine is the cervical part (Noordhoek et al., 2018). We conclude that the ACDF operations have tended to be conducted more often year by year: in 2013 - 25, in $2014-43$, in $2015-43$, in 2016 - 44, in 2017 - 48 (Fig. 2).

In our collected data, we separated patient groups by age and by gender. On average males were $46 \pm 1$ years old. Although females were older ( $50 \pm 1$ years), most of the patients were at their working age. In males, who work physically harder, spine problems occur earlier. In the present study the youngest patient was a 24-year-old woman, who had foraminal hernia at the C 6/7 level, approximately 7 $\mathrm{mm}$. She was a student, spending much time working on a computer. She had cervical pain with weakness and tingling of the right arm. In our study, females had 20\% more cervical part operations than males. We conclude that women are predisposed to develop cervical disc herniation because of anatomical features of the cervical part, such as smaller vertebral body and narrower endplates (Hermansen, 2015; Yao et al., 2018). Sometimes the reason is thinner and longer neck and weaker neck muscles, compared to males.

Our results indicated that the latest tendencies, new operation techniques and materials are introduced in daily praxis. In our collected data, four types of cages were used with different biophysical and biochemical properties: Syncage C, Cervious Chrono C, Cervious Peek and EIT 3D print. Of 198 ACDF operations, Syncage C implants were used in 41 cases, Cervious Chrono C in 47 cases, Cervious Peek in 52 and EIT 3D in 58 cases. Nowadays we prefer to use titanium printed cages, which adds higher quality to spine surgery. These cages are prepared for each patient individually with variable sizes and heights made by a 3-D machine. This gives a possibility to place an implant in a precise location and to minimize subsidence of the cage (Moussa et al., 2018).

In the present study ACDF surgery without plate and screws using different types of cages was a treatment option of cervical spine disease. In the literature, recent investigators have reported comparative analysis of ACDF using selflocking stand-alone PEEK cage with ACDF using cage and plate in the treatment of three-level cervical degenerative spondylopathy (Chen et al., 2016; Zhou et al., 2018). They demonstrated that ACDF using self-locking stand-alone cages showed similar clinical results as compared to ACDF using cages and plate fixation. This is consistent with our results, and therefore we prefer to use cages without plates for three- and four-level cervical micro discectomies because the self-locking stand-alone cage for ACDF may effectively restore the cervical physiological curvature, cause few complications, and lead to satisfactory outcomes Zhou et al., 2018)
As demonstrated in our study, the extent of surgery, defined by a number of discectomy levels, appears to increase in the last two years, as seen by 20 cases $(9.8 \%)$ of 3-level discectomies including $\mathrm{C} 3-\mathrm{C} 6$ and 4-level discectomy in two cases $(1 \%)$ presented from $\mathrm{C} 4-\mathrm{C} 7$. In all cases self-locking cages were used without plate and screws.

Nevertheless, our retrospective analysis demonstrates that, most often one-and two-level discectomies were done. The most prevalent lesion levels were $\mathrm{C} 6 / 7$ and $\mathrm{C} 5 / 6$, followed by $\mathrm{C} 4 / 5$ and $C 3 / 4$. The cervical region presents the largest range and variety of movement of the spine. Moreover, level of $\mathrm{C} 6 / 7$ is known as the most rigid cervical part leading to hyper ossification of the disc and to spontaneous fusion at thoracic part (Radhakrishna et al., 1994; Rao, 2003; Hermansen, 2015; Iyer and Kim, 2016).

Anterior cervical spine procedures have been associated with satisfactory outcomes (Kim et al., 2015). High preoperative pain intensity, non-smoking and male gender predicts a successful long-term outcome (Hermansen, 2015). However, the occurrence of troublesome complications, although uncommon, needs to be taken into consideration (Fountas et al., 2007). The overall complication rate is $13.2 \%$, such as dysphagia in $1.7 \%$, postoperative soft tissue swelling and hematoma in $1.7 \%$, dural penetration in $1.7 \%$, aggravation of pre-existing myelopathy in $0.9 \%$, symptomatic recurrent laryngeal nerve palsy in $0.9 \%$ and superficial wound infection in $0.9 \%$ (Tasiou et al., 2017). Cage subsidence is generally defined as $\geq 3 \mathrm{~mm}$ loss of height comparing postoperative intervertebral heights with height at last follow-up. Mean incidence of cage subsidence is $21 \%$ (Noordhoek et al., 2018). In our study we had a cage subsidence at C 6/7 level in 24\% when a Syncage C cage was inserted and one subsidence $(1.7 \%)$ with a EIT 3 D printed cage. Additionally, pseudo arthrosis developed in $9 \%$ cases when Cervios Chronos Peek $\mathrm{C}$ and Cervios C Peek cages were applied.

Thanks to new implant materials, instruments and an individualised approach, which is achieved by printed materials, complications like cage subsidence or protrusion into the adjacent vertebral body have become considerably less. The properties of osteoinductive implants ensure that the bony tissue of cartilage grows into the implant, thus making it more stable (Moussa et al., 2018).

\section{CONCLUSIONS}

The ACDF surgeries appear to be increasingly performed, particularly, in females. The most frequent approach of one or two levels is applied; including level C 6/7 in both genders. Nevertheless, in the last years three- and four-level ACDF have become one of the surgical opportunities. The type of cage inserted is not influenced by patient gender and age, while new technologies and biophysical and biochemical properties of the cage may influence the choice. AG and EG conceived the study. AO was responsible for anaesthesia and applied the same anaesthetic procedure in all the patients. AG and AO participated in the design and the admin- 
istration of the study. EG collected the retrospective data from records for analysis. AO, EG, KR and IV performed the statistical analysis and interpreted the data demonstrating them in result section. $\mathrm{AG}, \mathrm{EG}, \mathrm{AO}$, and $\mathrm{KK}$ drafted the manuscript. All authors read and approved the final manuscript.

This research received no external funding. The authors declare no conflict of interest.

\section{ACKNOWLEDGEMENTS}

We thank engineer Kārlis Bētiņš, Orto Clinic, Technical Department, for his kind assistance with uploading SPSS Statistics (Chicago, IL, Ver. 22) and with electronical assistance of collecting data from patient records.

\section{REFERENCES}

Bakhsheshian, J., Mehta, V. A., Liu, J. C. (2017). Current diagnosis and management of cervical spondylotic myelopathy. Global Spine J., 7 (6), $572-586$.

Chen, Y., Lu, G. Wang, B., Li, L., Kuang, L. (2016). A comparison of anterior cervical discectomy and fusion (ACDF) using self-locking stand-alone polyetherether ketone (PEEK) cage with ACDF using cage and plate in the treatment of three-level cervical degenerative spondylopathy: A retrospective study with 2-year follow-up. Eur. Spine J., 25 (7), 2255-2262.

Chong, E., Pelletier, M. H., Mobbs, R. J., Walsh, W. R. (2015). The design evolution of interbody cages in anterior cervical discectomy and fusion: A systematic review. BMC Musculoskelet. Disord., 16, 99.

Fountas, K. N., Kapsalaki, E. Z., Nikolakakos, L. G., Smisson, H. F., Johnston, K. W.,. Grigorian, A. A., Lee, G. P., Robinson, Jr, J. S. (2007). Anterior cervical discectomy and fusion associated complications. Spine (Phila Pa 1976), 32 (21), 2310-2317.

Fouyas, I. P., Sandercock, P. A., Statham, P. F., Nikolaidis, I. (2010). How beneficial is surgery for cervical radiculopathy and myelopathy? $B M J, \mathbf{3 4 1}$, c3108.

Hermansen, A. (2015). Clinical and patient-reported outcomes after anterior cervical decompression and fusion surgery. Linköping University Medical Dissertations No. 1443.

Iyer, S., Kim, H. J. (2016). Cervical radiculopathy. Curr. Rev. Musculoskelet. Med., 9 (3), 272-280.

Kim, H. J., Nemani, V. M., Piyaskulkaew, C., Vargas, S. R., Riew, K. D. (2016). Cervical Radiculopathy: Incidence and Treatment of 1,420 Consecutive Cases. Asian Spine J., 10 (2), 231-237.
Kim, J. H., Park, J. Y., Yi, S., Kim, K. H., Kuh, S. U., Chin, D. K., Kim, K. S., Cho, Y. E. (2015). Anterior cervical discectomy and fusion alters whole-spine sagittal alignment. Yonsei Med. J., 56 (4), 1060-1070.

Kurtz, S. M., Devine, J. N. (2007). PEEK biomaterials in trauma, orthopedic, and spinal implants. Biomaterials, 28 (32), 4845-4869.

Montgomery, D. M., Brower, R. S. (1992). Cervical spondylotic myelopathy. Clinical syndrome and natural history. Orthop. Clin. North. Amer., 23 (3), 487-493.

Moussa, A., Tanzer, M., Pasini, D. (2018). Cervical fusion cage computationally optimized with porous architected Titanium for minimized subsidence. J. Mech. Behav. Biomed. Mater., 85, 134-151.

Neill, K. O. (2016). ACDF: Anterior cervical discectomy and fusion. Spine-health, Nov. 14.

Nikolaidis, I., Fouyas, I. P., Sandercock, P. A., Statham, P. F. (2010). Surgery for cervical radiculopathy or myelopathy. Cochrane Database Syst. Rev., No. 1, CD001466.

Noordhoek, I., Koning, M. T., Jacobs, W. C. H., Vleggeert-Lankamp, C. L. A. (2018). Incidence and clinical relevance of cage subsidence in anterior cervical discectomy and fusion: A systematic review. Acta Neurochir (Wien), 160 (4), 873-880.

Portnoy, H. D. (2001). Anterior cervical discectomy and fusion. Surg. Neurol., 56 (3), 178-180.

Radhakrishnan, K., Litchy, W. J., O'Fallon, W. M., Kurland, L. T. (1994). Epidemiology of cervical radiculopathy. A population-based study from Rochester, Minnesota, 1976 through 1990. Brain, 117 ( Pt 2), 325-335.

Rao, R. (2003). Neck pain, cervical radiculopathy, and cervical myelopathy: Pathophysiology, natural history, and clinical evaluation. Instr. Course Lect., 52, 479-488.

Shamji, M. F., Massicotte, E. M., Traynelis, V. C., Norvell, D. C., Hermsmeyer, J. T., Fehlings, M. G. (2013). Comparison of anterior surgical options for the treatment of multilevel cervical spondylotic myelopathy: A systematic review. Spine (Phila Pa 1976), 38 (22 Suppl 1), S195-S209.

Tasiou, A., Giannis, T., Brotis, A. G., Siasios, I., Georgiadis, I., Gatos, H., Tsianaka, E., Vagkopoulos, K., Paterakis, K., Fountas, K. N. (2017). Anterior cervical spine surgery-associated complications in a retrospective case-control study. J. Spine Surg., 3 (3), 444-459.

Woods, B. I., Hilibrand, A. S. (2015). Cervical radiculopathy: Epidemiology, etiology, diagnosis, and treatment. J. Spinal Disord. Tech., 28 (5), E251-E259.

Yao, Q., Yin, P., Khan, K., Tsai, T. Y., Li, J. S., Hai, Y., Tang, P., Li, G. (2018). Differences of the morphology of subaxial cervical spine endplates between Chinese and white men and women. Biomed. Res. Int., 2018, 2854175.

Zhou, J., Li, J., Lin, H., Li, X., Zhou, X., Dong. J. (2018). A comparison of a self-locking stand-alone cage and anterior cervical plate for ACDF: Minimum 3-year assessment of radiographic and clinical outcomes. Clin. Neurol. Neurosurg., 170, 73-78.

Received 17 July 2018

Accepted in the final form 14 November 2018

\section{KAKLA DAL̨AS DISKEKTOMIJU RETROSPEKTĪVA ANALĪZE}

Mugurkaula kakla dạ̣as ķirurğiska ārstēšana var ievērojami uzlabot dzīves kvalitāti. Mērķis bija retrospektīvi izanalizēt kakla daḷas diskektomijas stabilizējošās operācijas, veiktas ar priekšējo pieeju mikroskopa kontrolē (ACDF, anterior cervical discectomy and fusion). Pētījums tika veikts ORTO klīnikā Rīgā, Latvijā, no 2013. līdz 2017. gadam, izvērtējot datus par 198 pacientiem. Tika veikta salīdzinoša analīze n,emot vērā pacienta dzimumu, vecumu, diagnozi, operācijas apjomu, implanta veidu un kopējo augstumu ar SPSS 22, $p<0,05$ apliecina statistisko ticamību. Operāciju skaitam ir tendence pieaugt: 2013. g. — 25 operācijas, 2014. g. — 43, 2015. g. — 38, 2016. g. — 44 un 2017. g. - 48 operācijas. Sievietēm tās veic ievērojami biežāk nekā vīriešiem, 117 (59\%) un $81(41 \%), p=0,003$. Sievietēm vidējais vecums bija $50 \pm 1$ gads, vīriešiem $46 \pm 1$ gads, $p=0,007$. Vidējais operācijas laiks bija $1.5 \pm 1$ stundas, vidējais hospitalizācijas laiks $3 \pm 1$ dienas. Izmantoti tika četri implantu veidi: Cervios Peek Chronos C (24\%), Syncage C (21\%), EIT 3D print (29\%), Cervios C Peek (26\%); $p=0,2$, neatkarīgi no pacienta vecuma vai dzimuma. Visbiežāk — 98 gadījumu — kopējais implantu augstums bija 6-10 mm. Maksimālais augstums bija $22 \mathrm{~mm}$, kur diviem pacientiem veica trīs un vienam četru līmeņu diskektomiju, nepielietojot papildus plātnes un skrūves. 
Disku bojājumi visbiežāk bija sastopami C5/6 un C6/7 līmeņos, tiem sekoja C4/5 un C3/4. Viena un divu līmeņu diskektomijas veica vienlīdz bieži 95 un 81 gadījumos, bet tikai 20 pacientiem bija trīs, un diviem četru līmeņu diskektomijas veiktas 2016. un 2017. gadā. Sievietēm statistiski biežāk divu līmeņu diskektomijas tika veiktas C5/6 un C6/7 līmen,os, attiecīgi 55 pret 26 vīriešu diskektomijām, $p=$ 0,01. Vīriešiem viena līmeṇa bojājumu visbiežāk konstatēja C6/7 līmenī, $p=0,04$. Tādu komplikāciju kā implanta iegrimšanu novēroja $5,5 \%$ gadījumu, bet, izmantojot SyncageC implantus, līdz pat $24 \%$ gadījumu. ADCF operācijas tiek veiktas aizvien plašāk, īpaši sievietēm. Vienu vai divu līmeņu diskektomijas, ietverot C6/7 līmeni, abiem dzimumiem veic visbiežāk. Pēdējos gados tiek realizēta arī trīs un četru līmeṇu diskektomiju kirurğiskā pieeja. Lai arī implanta izvēli neietekmē pacienta dzimums un vecums, to var ietekmēt implanta biofizikālās un bioḳīmiskās īpašības. 